\title{
The effect of customer relationship management on customer loyalty: Evidence from banking industry
}

\author{
Hadi Hajiyan $^{\text {a*}}$, Ali Akbar Aminbeidokhti ${ }^{\mathrm{b}}$ and Hadi Hemmatian ${ }^{\mathrm{a}}$
}

${ }^{a}$ Department of Management, Islamic Azad University, Semnan Branch, Semnan, Iran ${ }^{b}$ Department of Management, University of Semnan, Semnan, Iran

\section{H R O N I C L E A B S T R A C T}

Article history:

Received March 25, 2015

Received in revised format

August 162015

Accepted September 122015

Available online

September 142015

Keywords:

Banking industry

Customer relationship

management

Customer loyalty

Quality of services

\begin{abstract}
Measuring customer satisfaction in banking industry plays essential role for increasing market share and profitability. In this paper, we present an empirical investigation to measure the effect of customer relationship management (CRM) on customer loyalty in Iranian banking industry. The study aims to understand whether implementation of a good CRM could increase the quality of services. The study designs a questionnaire in Likert scale and distributes it among 65 selected customers who do their banking activities with Bank Melli Iran in city of Semnan, Iran. Cronbach alpha has been calculated as 0.939 , which is well above desirable level. Using t-student test, the study has determined that implementation of CRM could increase customer loyalty and quality of services.
\end{abstract}

\section{Introduction}

Measuring service quality plays essential role for the success of most business models especially in service industry where most insurance firms and banks actively try to develop their business activities through getting more market share (Parasuraman et al., 1988). In banking industry, customer says the last word and many business activities may shrink or develop through word of mouth advertisement (Newman, 2001). Kumar et al. (2009) determined the critical factors for evaluating the level of service quality of banks by re-examining the SERVQUAL model, originally developed by Parasuraman et al. (1988). In addition, the method of dominance analysis was also implemented to measure the relative importance of each critical factor in closing up overall service quality gap of banks. They reported that there were substantial differences between the respondents' expectation and their perceptions. Among the four dimensions of SERVQUAL examined, tangibility maintained the smallest gap whereas convenience yielded the biggest gap. They also reported that competence and convenience together could help to reduce the SERVQUAL gap significantly. According to their survey, the banking sector * Corresponding author. Tel: +989128310675

E-mail address: hadihajiyan61@yahoo.com (H. Hajiyan) 
requires to become more competent by being more responsive and fulfilling the assurance of the customers and providing the banking facilities more conveniently.

Ladhari et al. (2011) compared perceptions of bank service quality among Tunisian and Canadian customers, and tried to determine the dimensions of service quality, which could make the biggest contribution to overall customer satisfaction and loyalty. In their survey, in the Canadian sample, empathy and reliability were determined to be the most important predictors of satisfaction and loyalty, while in the Tunisian sample, reliability and responsiveness were considered as the most important predictors of satisfaction and loyalty.

Yavas et al. (2004) examined the nature of relationships between service quality, background characteristics, and satisfaction and some behavioral outcomes by applying retail banking in Germany as its setting. The survey reports that service quality was at the root of customer satisfaction and it was linked to such behavioral outcomes as word of mouth, complaint, recommending and switching. Nevertheless, various perspectives of service quality and consumer characteristics appeared to be related to different outcomes. For example, the results implied that tangible elements of service quality and being a female were more closely related to positive word of mouth and commitment. On the other hand, "timeliness" perspectives of service delivery were more closely associated with customer satisfaction, and complaint and switching behaviors.

Han and Baek (2004) investigated the antecedents and the consequences of service quality in online banking using an application of the SERVQUAL instrument. They showed that service quality was an antecedent factor of customer satisfaction and retention. Ladhari (2009) investigated the psychometric properties of SERVQUAL in the Canadian banking industry. Their results supported the dimensionality, reliability, convergent reliability, discriminant validity and predictive validity of the scale in this service setting. Therefore, SERVQUAL was believed to be a suitable instrument for evaluating bank service in the Canadian context; bank managers could apply this instrument to undertake continuous evaluation of their service quality. Their results also indicated that responsiveness and empathy were the most essential dimensions of overall service quality in the Canadian banking context. The survey also indicated that the service provided by employees could make the biggest contribution to bank customer satisfaction. Senyücel (2009) presented an evaluation of SERVQUAL instrument as bank selection criteria in the banking industry. Rahaman et al. (2011) used SERVQUAL technique for measuring customer satisfaction for selected banks in Bangladesh.

\section{The proposed study}

This paper presents an empirical investigation to measure the effect of customer relationship management (CRM) on customer loyalty in Iranian banking industry. The study aims to understand whether implementation of a good CRM could increase the quality of services. The study designs a questionnaire in Likert scale consists of 30 questions and distributes it among some selected customers who do their banking activities with Bank Melli Iran in city of Semnan, Iran. The sample size is calculated as follows,

$$
N=Z_{\alpha / 2}^{2} \frac{p \times q}{e^{2}},
$$

where $N$ is the sample size, $p=1-q$ represents the probability, $z_{\alpha / 2}$ is CDF of normal distribution and finally $\varepsilon$ is the error term. For our study we assume $p=0.5, z_{\alpha / 2}=1.96$ and $e=0.05$, the number of sample size is calculated as $N=59$. The proposed study of this paper distributes 65 questionnaires. Fig. 1 demonstrates personal characteristics of the participants. 


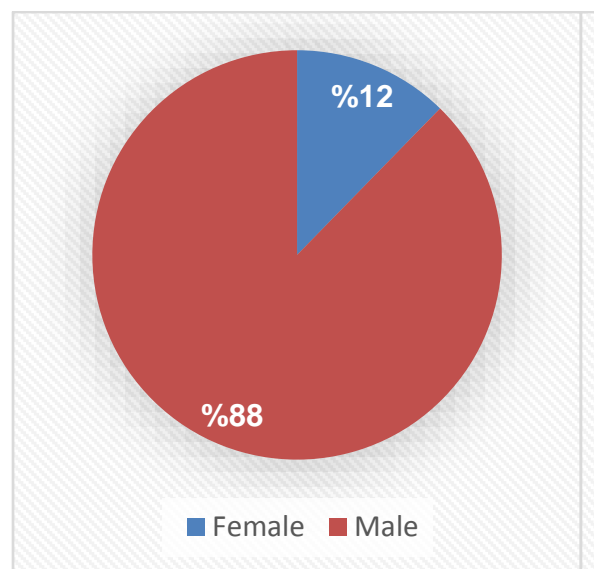

Gender

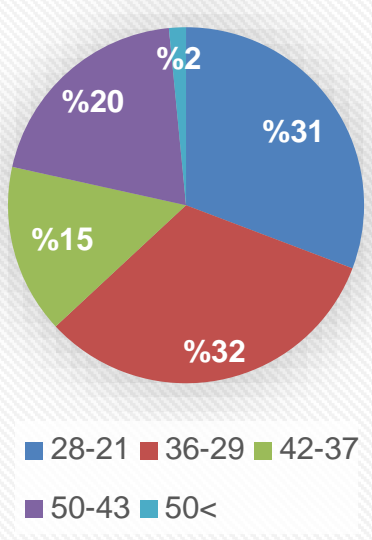

Age

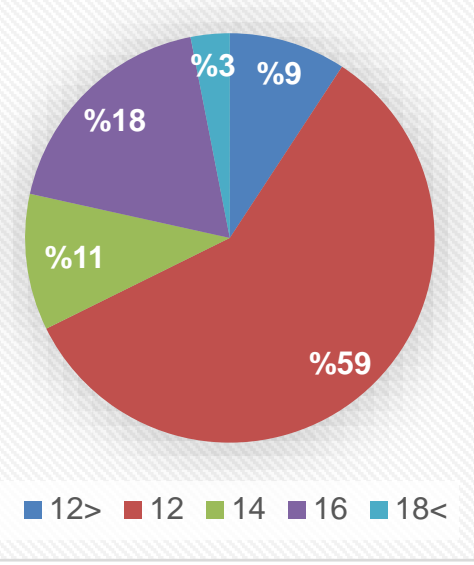

Education

Fig. 1. Personal characteristics of the participants

As we can observe from the results of Fig. 1, 88 percent of the respondents were male, $77 \%$ had no university education. In addition, most of the participants were middle aged people. The implementation of Kolmogorov-Smirnov test has indicated that the questionnaire data were normally distributed.

\section{The results}

In this section, we first present the effects of participants' personal characteristics on quality of services as well as customer loyalty.

\subsection{The effects of personal characteristics on quality of services and loyalty}

\subsubsection{The effects of customers' gender on quality of services and loyalty}

The proposed study of this paper uses Levene's test and t-test to measure the effects of gender on participants' personal characteristics on quality of services as well as customer loyalty. Table 1 demonstrates the results of our survey.

\section{Table 1}

The summary of Levene's test and t-test on the effects of gender on quality of services and loyalty

\begin{tabular}{llccccc}
\hline & & \multicolumn{3}{c}{ Levene's test } & \multicolumn{1}{c}{ t-test } \\
\cline { 2 - 7 } & & $\mathrm{F}$ & Sig. & $\mathrm{t}$ & $\mathrm{df}$ & Sig. \\
\hline Quality of services & $\mathrm{H}_{0}: \sigma_{1}{ }^{2}=\sigma_{2}{ }^{2}$ & 1.452 & 0.233 & 0.082 & 63 & 0.935 \\
& $\mathrm{H}_{1}: \sigma_{1}{ }^{2} \neq \sigma_{2}{ }^{2}$ & & & 0.064 & 8.081 & 0.950 \\
\hline Customer loyalty & $\mathrm{H}_{0}: \sigma_{1}{ }^{2} \sigma_{2}{ }^{2}$ & 0.025 & 0.875 & -1.205 & 63 & 0.233 \\
& $\mathrm{H}_{1}: \sigma_{1}{ }^{2} \neq \sigma_{2}{ }^{2}$ & & & & 9.132 & 0.255 \\
\hline
\end{tabular}

As we can observe from the results of Table 1, gender has no meaningful impact on quality of services and loyalty.

\subsubsection{The effects of customers' age on quality of services and loyalty}

The proposed study of this paper uses ANOVA test to measure the impact of age on participants' personal characteristics on quality of services as well as customer loyalty. Table 2 demonstrates the results of our survey. 
Table 2

The summary of ANOVA test on the effects of age on quality of services and loyalty

\begin{tabular}{llccccc}
\hline & & Sum of Squares & df & Mean Square & F & Sig. \\
\hline Quality of services & Between group & 233.235 & 4 & 58.309 & 0.539 & 0.708 \\
& Within group & 6489.227 & 60 & 108.154 & & \\
\cline { 2 - 7 } & Total & 6722.462 & 64 & & & 0.210 \\
\hline Customer loyalty & Between group & 490.010 & 4 & 122.502 & 1.514 & \\
& Within group & 4856.236 & 60 & 80.937 & & \\
\cline { 2 - 7 } & Total & 5346.246 & 64 & & & \\
\hline
\end{tabular}

As we can observe from the results of Table 2, age has no meaningful impact on quality of services and loyalty.

\subsubsection{The effects of customers' educational background on quality of services and loyalty}

Once more, the study uses ANOVA test to measure the impact of educational background on participants' personal characteristics on quality of services as well as customer loyalty. Table 3 demonstrates the results of our survey.

Table 3

The results of ANOVA test on the effects of educational background on quality of services and loyalty

\begin{tabular}{llccccc}
\hline & & Sum of Squares & $\mathrm{df}$ & Mean Square & $\mathrm{F}$ & Sig. \\
\hline Quality of services & Between group & 758.150 & 4 & 189.538 & 1.907 & 0.121 \\
& Within group & 5964.311 & 60 & 99.405 & & \\
\cline { 2 - 7 } & Total & 6722.462 & 64 & & & 0.033 \\
\hline Customer loyalty & Between group & 843.994 & 4 & 210.999 & 2.812 & \\
& Within group & 4502.252 & 60 & 75.038 & & \\
\cline { 2 - 7 } & Total & 5346.246 & 64 & & & \\
\hline
\end{tabular}

As we can see from the results of Table 3, while educational background has no meaningful impact on quality of services, it has some impact on customer loyalty when the level of significance is $5 \%$.

\subsection{Main hypotheses}

In this study, we examine the effects of customer relationship management on quality of services and customer loyalty as follows,

1. Customer relationship management has meaningful impact on quality of services.

2. Customer relationship management has meaningful impact on customer loyalty.

\subsubsection{First hypothesis: The effect of CRM on quality of services}

The first hypothesis of the survey examines the effect of CRM on quality of services and Table 4 shows the results of one-way test.

\section{Table 4}

The results of one-way test on measuring the effect of CRM on quality of services.

\begin{tabular}{lcccccc}
\hline & $\mathrm{t}$-value & $\mathrm{df}$ & Sig. & Mean difference & $95 \%$ confidence interval \\
\hline Quality of services & 10.105 & 64 & 0.000 & 85.641 & 0.6871 & 1.0257 \\
\hline
\end{tabular}

According to the results of Table 4, CRM has maintained a meaningful impact on quality of services when the level of significance is one percent. Therefore, the first hypothesis of the survey has been confirmed. 


\subsubsection{Second hypothesis: The effect of CRM on customer loyalty}

The second hypothesis of the survey examines the effect of CRM on customer loyalty and Table 5 demonstrates the results of one-way test.

\section{Table 5}

The results of one-way test on measuring the effect of CRM on customer loyalty.

\begin{tabular}{lllcccc}
\hline & t-value & df & Sig. & Mean difference & 95\% confidence interval \\
\hline Quality of services & 11.915 & 64 & 0.000 & 0.90051 & 0.7495 & 1.0515 \\
\hline
\end{tabular}

According to the results of Table 5, CRM has maintained a meaningful impact on customer loyalty when the level of significance is one percent. Therefore, the second hypothesis of the survey has been confirmed.

\section{Conclusion}

In this paper, we have presented an empirical investigation to study the effects of having good customer relationship management on quality of services and customer loyalty in banking industry. The study has designed a questionnaire in Likert scale consists of 30 questions, 15 for quality of services and 15 for customer loyalty, and distributed among randomly selected customers who regular customers of Bank Melli Iran in city of Semnan, Iran. Using ANOVA test, the study has determined that gender and age had no impact on quality of services and customer loyalty. Moreover, while educational background had no meaningful impact on quality of services, it had some impact on customer loyalty when the level of significance is 5\%. In addition, the implementation of t-student test has confirmed that CRM implementation could increase quality of services and customer loyalty. The results of our survey are consistent with findings earlier reported by Ladhari (2009), Ladhari et al. (2011) and Rahaman et al. (2011). Ariff et al. (2013) examined the relationship and the effects of e-SQ and eSatisfaction on e-Loyalty in internet banking. They used a modified version of E-SERVQUAL instrument to determine e-SQ for internet banking service of a commercial bank in Malaysia. They highlighted similar results with findings of this survey.

\section{Acknowledgement}

The authors would like to thank the anonymous referees for constructive comments on earlier version of this paper.

\section{References}

Ariff, M. S. M., Yun, L. O., Zakuan, N., \& Ismail, K. (2013). The impacts of service quality and customer satisfaction on customer loyalty in internet banking. Procedia-Social and Behavioral Sciences, 81, 469-473.

Han, S., \& Baek, S. (2004). Antecedents and consequences of service quality in online banking: An application of the SERVQUAL instrument. Advances in Consumer Research, 31(2), 208-14.

Kumar, M., Tat Kee, F., \& Taap Manshor, A. (2009). Determining the relative importance of critical factors in delivering service quality of banks: an application of dominance analysis in SERVQUAL model. Managing Service Quality: An International Journal, 19(2), 211-228.

Ladhari, R. (2009). Assessment of the psychometric properties of SERVQUAL in the Canadian banking industry. Journal of Financial Services Marketing,14(1), 70-82.

Ladhari, R., Ladhari, I., \& Morales, M. (2011). Bank service quality: comparing Canadian and Tunisian customer perceptions. International Journal of Bank Marketing, 29(3), 224-246.

Newman, K. (2001). Interrogating SERVQUAL: a critical assessment of service quality measurement in a high street retail bank. International journal of bank marketing, 19(3), 126-139.

Parasuraman, A., Zeithaml, V. A., \& Berry, L. L. (1988). Servqual. Journal of retailing, 64(1), 12-40. 
Rahaman, M. M., Abdullah, M., \& Rahman, A. (2011). Measuring service quality using SERVQUAL model: A study on PCBs (Private Commercial Banks) in Bangladesh. Business Management Dynamics, 1(1), 01-11.

Senyücel, E. (2009). Evaluation of SERVQUAL instrument as bank selection criteria in the banking industry: Empirical evidence from Turkish and Greek speaking areas in Cyprus. Banking and Finance Letters, 1(1), 21.

Yavas, U., Benkenstein, M., \& Stuhldreier, U. (2004). Relationships between service quality and behavioral outcomes: A study of private bank customers in Germany. International Journal of Bank Marketing, 22(2), 144-157. 